CRITICA, Revista Hispanoamericana de Filosofia

Vol. XXIV, No. 70 (abril 1992): 65-82

\title{
DELIGHTFUL, DELOVELY AND EXTERNALIST
}

JANE DURAN

University of California at Santa Barbara

The debate between the externalists and internalists is often couched in such language as to render its true nature difficult to discern. Those who are trying to defend the internalist position, or even to describe it, or give a proper account of it, frequently invoke Descartes and Cartesian privileged access - with good reason perhaps, but there is much more to the internalist position than that. Those who become involved in the externalist position frequently allude to causal chains, or events outside of the consciousness of the epistemic agent, or to situations of which the agent might be aware, but is not currently aware.

The enormous amount of literature churned out about the debate veils, I argue, the more pressing matter of the future and long-term goals of epistemology. Not that that has not also come up for grabs - the contretemps surrounding the naturalization of epistemology illustrates that little can at this point be taken for granted by professional epistemologists. But then again, the crux of the naturalizing epistemology debate is, I contend, related to whatever is gotten at in the internalist-externalist debate - so much so that $I$ also assert that these two areas of focus amount to really one area of focus: whether and how much epistemology is reducible, and what the nature of its reduction ought to be.

Writing in Neurophilosophy, Patricia Smith Churchland argues against those who would contend that the computation- 
al account of mental functioning is irreducible because of the allegedly logical nature of the relations specified by the computational model. ${ }^{1}$ But the greatest area of interest in this debate for epistemologists is not the question of reduction, but the question of modeling the relevancy of mental modeling itself. To be still more specific, not whether the mind can and should be modcled - since the empirical sciences of the mind seem to leave us with little doubt on that score- but whether any modeling of the mind is relevant to epistemology as practiced by professional philosophers. For the stringently normative nature of the tradition has always rejected any view of the functioning of epistemic agents as relevant to the traditional questions of epistemology, e.g., the nature of knowledge, proper account of epistemic justification, and so forth. ${ }^{2}$ In other words, one would like to be able to say that the questions posed by a work such as Neurophilosophy are just as relevant to epistemologists as they are to philosophers of mind but, remarkably, the history of thesc two projects reveals that this has not been the case so far.

Recently, work by Goldman, Kornblith and others ${ }^{3}$ seems to be pointing cpistcmology as a discipline in a new direction. The idca seems to be that we ought to admit that advances in the cognitive sciences have been so great and so rapid that it seems somewhat foolish, if not actually futile, to attempt to discuss cven normative philosophical issucs surrounding knowledge and knowledge-acquisition without making allusion to some of

1 Patricia Churchland Smith, Neurophilosophy, Cambridge, Mass., Bradford Press of MIT, 1986.

2 I have alluded to the nature of the tradition in other pieces, see for example, my "Descriptive Epistemology", in Metaphilosophy, Vol. 15, Nos. 3-4.

3 In addition to the obvious works by Goldman and by Komblith (Alvin Goldman, Epistemology and Cognition, Ilarvard University Press, 1986; IJilary Komblith, Naluralizing Epistemology, Bradford Press of MIT, 1985), I also cite Naturalism and Rationality, Newton Garver and Peler I Iare, eds., Buffalo, N.Y., Prometheus Books, 1986. 
these advances. Now if one can accept that this is the case - that is, that epistemology can benefit from taking into account the functioning of epistemic agents - then the question of the nature of the model of mind chosen to illustrate such functioning becomes, of course, much more important, and inter alia the question of whether such a model is susceptible to reduction itself becomes a question of some importance. For once having chosen the model, one might feel somewhat bereft intellectually if one were convinced that one's model would in twenty or thirty years reduce to a very precise and empirically confirmable account of the functioning of neurons and synapses.

It is this question of modeling - and its corollary question of reducibility - that is at the heart of the internalist-externalist debate, even if it is not immediately obvious. For what the externalist is entitled to count as conditions external to the mind of the agent which might give rise to knowledge includes conditions about the mind or mental faculties of the agent, so to speak, insofar as those faculties and their functioning are not accessible internally to the agent himself. This is why reliabilism is an externalist, not internalist theory, and this is why externalism leaves so many more traditonally-minded epistemologists so thoroughly dismayed. For if it is not necessary for the agent to have cognizance of her beliefs, or for her to be able to produce the line of rcasoning which she would ordinarily (on an internalist view) employ as justification, what has the delineation of knowlcdge conditions become but an exercise in specifying conditions of matter which give rise to knowledge? And how then is epistemology anything more than a reductionist exercise in applying the methods of the sciences to questions formerly considcred to be beyond the purview of the sciences? Reduced epistemology has no more glamor than reduccd philosophy of mind.

Externalism is the view par excellence of the naturalizing epistemologist. And externalism, I shall argue, is what is re- 
quired to give an account of knowledge with which we can live, given that we are indeed living in the latter half of the twentieth century.

In his piece "Externalist Theories of Empirical Knowledge", Bonjour seems to think that it constitutes some sort of argument against what he takes to be the externalist viewpoint that it is somehow odd, unusual, or outside the mainstream philosophical tradition. The following passage is illustrative of Bonjour's contention that externalism is somewhat recherche and arcane from the outset:

When viewed from the general standpoint of the Western epistemological tradition, externalism represents a very radical departure. It seems safe to say that until very recent times, no serious philosopher of knowledge would have dreamed of suggesting that a person's beliefs might be epistemically justified simply in view of facts or relations that were external to his subjective conception. Descartes, for example, would surely have been quite unimpressed by the suggestion that his problematic beliefs about the external world were justified if only they wcre in fact reliably related to the world - whether or not he had any reason for thinking this to be so. ${ }^{4}$

Leaving aside for the moment Bonjour's gloss on externalism as holding that beliefs are justified if they are "reliably related to the world" (a point to which I shall return), the use of Descartes as a putative arbiter and the implicitness of internality as part and parcel of justification manifest the tendencies to which I have alluded in the preceding paragraphs. Externalism ranklcs some, at least, from the outset because it appears to be

4 Laurence Bonjour, "Extemalist Theories of Empirical Knowledge", in Midwest Studies in Philosophy, Vol. V, Minneapolis, University of Minnesola Press, 1980, p. 56. 
something entirely apart from the usual methods of epistemology. In so much, I believe, the epistemologists who hold this view are correct - but this does nothing to help us respond to a query about the correct account of knowledge without begging the question. Why must it be the case that to provide a correct account of knowledge —or even of epistemic justificationan internalist viewpoint is assumed, and to attempt to stand outside it is to go against the grain?

As Bonjour seems to imply, the influence of the Cartesian tradition is partly to blame, but also partly to blame is the normative nature of epistemology itself. The questions we are supposed to have been answering have frequently been framed along the lines of "what our correct account of knowledge ought to be", with it being understood that the force of ought here has something to do with the notion of an ideal knower operating under ideal epistemic conditions. These two sorts of assumptions have snowballed, so to speak, into one overwhelming assumption - that the account we are seeking is internalist and normative. The effect of this, has been, of course, to omit from our theorizing any allusion to the way in which epistemic agents actually function, no matter how relevant such allusion might be.

Now Bonjour's work here is important not only for its influence, and not only because the preceding quotation helps crystallize a certain sort of outlook. In addition, in arguing against externalism, Bonjour also commits some of the same sorts of errors of which he accuses others. I want simultaneously to be precise about how this happens, taking Bonjour's work as paradigmatic, and to show how the sorts of assumptions Bonjour makes militate (if taken seriously) against our getting clear on things epistemically.

At the opening of his "Extcrnalist Theories" piece, Bonjour makes two rather remarkable assumptions. One is that foundationalism —or at least some foundationalism - can be externalized. Hc cites a portion of Armstrong's work, which describes a stopping point for knowledge claims of reliable nom- 
ic relations, as an externalized foundationalism. ${ }^{5}$ Precisely because foundationalism relies on beliefs with peculiar epistemic status, one normally thinks of classical foundationalism as a decidedly internalist view, although there is certainly at least an analogue between standard foundationalism and reliabilism simpliciter. ${ }^{6}$ More oddly still, however, while preparing to attack Armstrong's view, Bonjour informs us that this view, with its externalist structure, is designed to solve the foundationalist regress problem. ${ }^{7}$ Now what is so unusual about this, I claim, is the following —even if we can accept Armstrong's view as a kind of foundationalism, the classical foundationalist regress problem, as normally posed, is posed in internalist terms. Bonjour, in fact, does pose the problems in such terms at the very beginning of his article. ${ }^{8}$ Since the regress problem is a problem statedly about beliefs as they are held, it is, of course, difficult to see how an externalist view could solve that problem formulated in that way. In other words, the point is that cxternalism may help us in any one of a number of ways, and yet it depends to some extent on how epistemic problems are posed. If one insists on posing the problems as if they were internalist problems and as if the tradition could function only in an internalist fashion, then of course externalist solutions look as if they do not work. And yet this is precisely what Bonjour does. Witness the following counterexample, taken from a

5 What Bonjour says is that Armstrong is an "externalist", and that he makcs "basic belief [such beliefs being one of the hallmarks of foundationalisin] depend on an external relation", p. 57.

I have made this argument in my "Reliabilism, Foundationalism and Naturalized Epistemic Justification Theory", in Metaphilosophy, Vol. 19, No. 2.

7 Bonjour: "Hcre I am concerned about the more fundamental issue of whether Armstrong's view, or any other externalist view of this general sort. is acceptable as a solution to the regress problem and the basis for a foundationalist account of empirical knowledge." In op. cit., p. 58.

See op. cil., p. 54. 
typical of several of the examples he utilizes to argue against externalist views:

Case III. Maud believes herself to have the powers of clairvoyance, though she has no reasons for this belief. She maintains her belief despite being inundated by her embarrassed friends and relatives with massive quantities of apparently cogent scientific evidence that no such power is possible. One day Maud comes to believe, for no apparent reason, that the President is in New York City, and she maintains this belief, despite the lack of any independent evidence, appealing to her alleged clairvoyant power. Now in fact the President is in New York City, and Maud does, under the conditions then satisfied, have completely reliable power. Moreover, her belief about the President did result from the operation of that power.

This example is similar to two others used by Bonjour to make essentially one point: Maud does not have knowledge because Maud is not justified. Specifically, Bonjour says: "Maud $[\ldots]$ is not justified in her belief about the Prcsident and does not have knowledge." ${ }^{10}$ But to say that this analysis of the problem is question-begging severely understatcs the case. Of course Maud has knowledge. She has knowlcdge bccause there is such a power as clairvoyance, ex hypothesi, and Maud is a possessor of it. The fact that traditional internalist analyses of the situation would seem to leave us with Maud's not being justified here is something which ought to count against the traditional internalist analyses, and not against the example. The example is a bit forced because a negative cffect is already produced by mentioning clairvoyance, an allcged cognitive capacity for which we currently do not have enough evidenee. But a number of other examples could be concocted utilizing powers we do already possess — combinations of long-term memory, sensory modification, dreams, and so forth - which

\footnotetext{
9 Ibid., p. 61.

${ }^{10} \mathrm{Jbid}$.
} 
would speak to the same point. The point is simply that the counterexamples to internalist analyses are so obvious and legion in number that the interference to which we are drawn is that a correct account of knowledge — particularly an account which attempts to utilize anything like a contemporary model of mind - will inevitably be externalist.

Bonjour goes on to defend an internalist coherence view, but more needs to be said about some of the standard sorts of things taking place in the internalist/externalist debate. In a paper entitled "The Internalist Conception of Justification", Goldman is quite helpful in his formulation of what makes externalism so unappealing to most epistemologists:

The foregoing conception [is] 'externalist' perspective: the perspective of a God-like observer who, knowing all truths and falsehoods, can select the DDP that optimally conduces to true belief and error avoidance. Traditional epistemology has not adopted this externalist perspective. It has been predominantly internalist, or egocentric. ${ }^{11}$

In general Goldman is able to give a better account than Bonjour of the terms of the debate, for Goldman arliculates what should be obvious: For the most part, we are not aware of our cognitive processes, and the requirement that a correct Doxastic Decision Principle have some degree of sclf-referentiality built into in virtually guarantees that we will not be able to give a cognitively correct account, whatever other virtues such an account might possess. As Goldman argues, we generally do not know how our beliefs are caused. ${ }^{12}$ Even if a better account of knowledge were somehow reliabilist —and Goldman identifies reliabilist accounts as externalist - the very fact that we would want to allude to cognitively reliable process-

11 Alvin Goldman, "The Internalist Conception of Justification", in Midwest Studies, op. cit., p. 32.

12 Ibid., p. 35. 
es in such an account would almost certainly preclude our making such an account internalist.

A crude gloss on what we now know about cognitive modeling and neural functioning would seem to leave us with the following: Providing a correct account of how we come to know will at some point require some allusion to cognitive or neural processes, and, again at some point, delineation of these processes will pass beyond the level at which the processes could in any sense be said to be conscious. So, the response goes, does this mean that such an account is some mysterious sort of non-knowledge account -non-epistemological and simply the stuff of which psychology, neurology, neuropsychology or some other discipline is made? Or does this mean, on the other hand, that we ought to take such theorizing into account in epistemology because it represents the best that is currently available and, insofar as it purports to describe human cognitive functioning, is inevitably relevant to the acquisition of knowledge? Common sense, not to say theoretical perspicacity, requires that we answer the first question in the negative and the second question in the affirmative. Epistemology can and should be naturalized, at least to the extent that what we recommend for our knowers is something which can actually be instantiated by knowers. To this end, it appears that an externalist account is what is required.

\section{II}

That an externalist account of knowledge is essentially a correct account of knowledge becomes more evident when we try to utilize what we now know about cognitive functioning in juxtaposition with what was formely called, in happier times, our "intuitions" about knowledge.

The Gettier examples were originally successful precisely because they ran in one direction with our intuitions about cases of knowledge and knowing. Writing shortly after the height 
of ordinary language philosophy, Gettier was able to use our commonsense, everyday notions about what constitutes a case of knowing to construct counterexamples to a tight version of the three-pronged Justified True Belief thesis. In the original piece, one of the variations asks us to consider whether we know the proposition "Jones owns a Ford or Brown is in Barcelona" when it turns out (to explain the example very briefly) that Jones, who always owned a Ford before, is now only renting one, and Brown, whose whereabouts were complctely unknown to us, actually is in Barcelona, but this is only (epistemically) accidental good fortune. Gettier seems to think - and apparently he was right in so thinking - that we would not count it as a case of knowledge that the disjunction is true only because the second disjunct is "accidentally" true, thus preserving the truth of the whole. As Goldman had written in a piece published shortly thereafter, if we had any evidence at all that Brown was in Barcelona — such as a postcard — we might not be inclined to dismiss this as a case of knowledge so lightly. ${ }^{13}$

But, of course, one's intuitions about knowledge vary, and these arguments can be used to run in the other direction. More importantly, the fact that ordinary language conditions seem to indicate a reluctance on our part to countenance epistemic luck as knowledge, or to allow the accidental to count in areas where we normally would require justification, really does not tell us anything about knowledge simpliciter. If it tells us anything at all, it tells us about how language is used, somewhat unreflectively, no doubt, and only under certain conditions. The hard cases are cases which are really not amenable to an ordinary language or intuitive view because too many important questions are at stake.

In "Some Social Features of Cognition", Kornblith reminds us that a great deal of the knowledge acquisition which takes

13 Alvin Goldman, "A Causal Theory of Knowing", in Essays on Knowledge and Justification, George S. Pappas and Marshall Swain, eds., Ithaca, N.Y., Cornell University Press, 1978, p. 68. 
place in human beings, particularly in childhood, is unconscious, largely out of our control, and also seemingly guided by social factors of which we are largely unaware. ${ }^{14}$ In fact, as Kornblith argues, if we do become aware of these factors (presumably at a later point in our lives) we may judge these factors to be, as he phrases it, epistemically "pernicious", rather than epistemically beneficial. ${ }^{15}$ But if we do so judge these factors, we are wrong. Experience indicates that the social factors which influence cognition are beneficial, not pernicious, a significant amount of the time. Here is Kornblith:

A tendency to take on the beliefs of others [manifested, for example, in the well-known Asch experiments] is not one which is self-consciously acquired. Indeed, it does not seem to be acquired at all; rather, as we have seen in Section 1, this tendency seems to be innate [But] the typical case is simply that the agent does not come to realize that he has the tendency, nor does the output of the tendency typically cause the agent to question whether there might be something wrong with his processes of belief acquisition. Thus, from the agent's perspective, there is no reason to change his epistemic practice. In virtue of this, I take the agent to be justified. ${ }^{16}$

It is important to note here why it is that Kornblith, as he puts it, takes the "agent to be justified". Hc takes the agent to be justified because, as he goes on to say, these tendencies are "reliable". ${ }^{17}$ That is, the tendencies result in truth acquisition more often than not. And yet, as Kornblith admits, nothing internal —nothing from the agent's perspective- forces or even suggests to the agent that she ought to admit this. Indced, most agents are unaware of what thcy are doing, and

14 II lary Komblith, "Some Social Features of Cognition", Synthese, 73, 1987, pp. 27-41.

15 Ibid., p. 39.

16 Ibid., pp. 38-39.

17 Jbid., p. 40. 
as Kornblith also says, in an odd sense the tendency is internally justified because "people tend to be ignorant of the existence of this proposition. As a result, nothing strikes them as worthy of change when they are motivated by a desire for truth."18

But if this is an internal justification at all, it is indeed an odd one. It would count as odd because there is nothing internal about it. Nothing in the agent's repertoire comes to consciousness, and nothing about the tendency to acquire the beliefs of others undergoes a process of revision, at least not on the conscious level. The truth is, of eourse, that this is not an internalist perspective at all. Only a stirring devotion to the Cartesian tradition would encourage one to think in these terms. The account of knowledge which allows us to use the results of the Asch experiments (experiments in which subjects typically revised their perceptual data on the basis of erroneous feedback from others whom they took to be trustworthy) is an externalist account. The three-year-old child is hardwired, so to speak, to turn to adults in times of crisis and further hardwired to take in most of the information with which they provide her, in many instances unquestioningly. Whether this all works out epistemically, to phrase it crudely, is a question which can only be decided from an external perspective. And the answer from an external perspective, according to Kornblith and others, is that it does.

III

What we need to try to be more precise about externalism is an account which helps us fill in the way the three-year-old -or anyone else for that matter- actually obtains her information. What is needed is not necessarily a reliabilist account, for reliabilism as so far developed has been remarkably unspecific

18 Ibid., p. 39. 
about what cognitive processes will count as the reliable cognitive process. ${ }^{19}$ We need some account which will tell us how the process of epistemic justification proceeds, how knowledge is acquired, and which does so in a way which is non-internalist.

Fortunately, recent work in cognitive science gives us some hope that such an account may be forthcoming. Although much of what epistemologists have utilized from cognitive science to date has been more in the nature of the computational model of mind,${ }^{20}$ the new connectionist model can provide us with at least a glimmer of what goes in the three-year-old's head. The social process to which Kornblith alludes can be modeled at least partially by trying to construct a sketch of response-toquestioning which is sensitive to both some of the large-scale moves (speech act, Script/Goal, etc.) and some of the smaller, neural or neural network moves which would have to be made by an epistemic agent.

In previous account I have depicted the epistemic agent as proceeding along crudely coherentist lines, where justification of a knowledge claim accrues through comprehension of the skeptical challenger's claim, production on the afferent level of an output which is aimed at getting acquiescence from the challenger, or even silence, change in internal state of the epistemic agent in response to the challenge, and so forth. ${ }^{21} \mathrm{My}$ model, like most of the other naturalized and semi-naturalized accounts, relied on the model of mind available at that time, the computational model. But the Rumelhart and McClelland data seem to provide us with fruitful opportunity for still further development, and so emendations can be made in the model along connectionist lines.

\footnotetext{
19 See my "Reliabilism, Foundationalism", in op. cit.

20 It is in general this model which appears, for example, in the work of Goldman.

21 I have developed this model in both "A Contextualist Modification of Cornman", in Philosophia, Vol. 16, Nos. 3-4, and "Reliabilism, Foundationalism", in op. cit.
} 
My previous model relied on two notions: intentionality and input-output conditions. Broadly speaking, the heart of the model was that, descriptively, epistemic agents engage in the process of justification by understanding challenges as such (on the level of intentionality) and then altering the utterances into encoded symbol information which has its own sct of semantically-available interpretations -only in the cases, of course, where the utterances are not processed as sheer noise. But the connectionist model has the virtue that it allows us to be specific about microstructure activities. Hence I propose the following as a naturalized, externalist view of the justificatory set:

(i) The justifying set is picked out on the grounds of contextual constraint (that is, some sentences are naturally omitted as possible justifiers since, on any coherence system, they are not relevant to the topic at hand).

(ii) The delineation of the set amounts to: specification of each alleged justifier for statement-to-be-justified $x$ results from a process of epistemic intent on the part of the skeptical agent or challenger and recognition of such intent, in Gricean terms, on the part of the agent.

(iia) More specifically, the utterance of the challenger, once heard by the agent, taps into the distributed memory system as recognized semantic material (I do not here deal with non-recognizable cases) and activates a pattern over units in a subset of modules. The network of units is interconnected and sends signals which may be assigned various modulated weights.

(iia') These units activate still higher-order transformational units which, under a variety of constraints not modeled at the micro-level (such as Schank's Script/Goal constraints, or speech-act constraints) yield utterances which are 
themselves the alleged justifiers which then constitute the justificatory set.

(iia") If not recognized semantic material, the challenger's utterances are interpreted as noise.

(iii) The utterances are recognized by the agent as intended to produce a state of doubt.

(iv) For closure of the entire process, and production of a set of statements which may be specified descriptively as the justificatory set, the challenger must recognize as justifiers, and such recognition is given either by verbal or non-verbal acquiescence to the agent's justifiers, or failing that, by further challenges, in which case the process is iterative.

My model does not provide, and is not intended to provide, an account of justification in standard normative, internalist terms. As I have argued, such terms generally adhere to conditions inherited from the Cartesian tradition, and within the framework of that tradition the genealogy of statements becomes overwhelmingly important when truth-seeking is the goal. But the standard internalist account cannot give anything like a cognitively accurate portrayal of the process of knowledge acquisition. That alone should make one suspicious of such an account, even if most of the standard accounts did not suffer from other sorts of defects on their own terms. As Kornblith has argued, the processes of belief acquisition - for which we are hardwired- are beneficial rather than pernicious. These processes result in knowledge acquisition most of the time, even if we can only, on some occasions, be much less specific than we would like to be about what is going on or what knowledge will result. The mistake, I claim, is to continue to think in terms of an internalist perspective (or even internalist labeling) when it is clearly an extcrnalist account which is called for. 
IV

In this paper I have argued that the strength of the influence of internalism on our epistemological perspective has been overwhelming, and has prevented us from making moves in epistemology - such as naturalization, where we have enough information to naturalize - which ought to have ocurred long ago. I have argued that philosophy of mind ought to be more important to epistemologists than it sometimes has been, and that whether or not certain questions in philosophy of mind can be answered by reductionist ploys is a very important question for those laboring in theory of knowledge. I have cited some of Bonjour's work as a primary example of question-begging with regard to the internalist/externalist debate, and have cited both Goldman and Kornblith as providing us with more valuable accounts. The greatest argument for externalism remains simply this: Knowledge acquisition cannot always be accounted for consciously, and any attempt to spell out the process of knowledge acquisition precisely invariably involves cognitive processes to which the agent could not, under any conditions, have access. The more we know or hypothezise about various mental models, the more inclined we are to be less than sympathetic to counterexamples constructed from the older traditions of theory of knowledge which assume that a piece of information ought not to count as knowledge simply because it is received by the epistemic agent through unconscious or unspecifiable processes, or (worse still) simply because we would not ordinarily refer to the information as a piece of "knowledge". Clairvoyance may or may not exist. But the odd virtue of clairvoyance as an example of inexplicable mental process is that many mental processes for which we do currently have evidence are only slightly more explicable, at the moment, than clairvoyance, by hypothesis, would be. The three-year-old child is hardwired to obtain information, and most of the time, given a benevolent environment, the information turns into knowledge. The ten- 
dencies which lead to this information acquisition are innate, frequently inarticulable and largely unconscious. But thcy are susceptible to advances in psychology and other areas of the cognitive sciences, and so much the better, I argue, for epistemology.

Recibido: 17 de abril de 1991. 


\section{RESUMEN}

Se han desarrollado tres argumentos principales para apoyar un modelo externalista de justificación y de conocimiento epistémico. El primer argumento nos pide nombrar nuevamente los orígenes de modelos internalistas y nos recuerda que el trabajo contemporáneo sobre ciencia cognitiva y epistemología naturalizada está relacionado con estos textos. Un segundo argumento señala deficiencias en el análisis del externalismo en la obra de Bonjour y también se refiere al trabajo de Goldman. El tercer argumento trata el concepto de Kornblith que se refiere a que estamos condicionados para la adquisición de conocimientos de diversas maneras que comprenden procesos inconscientes y no susceptibles de explicaciones en primera persona. Se concluye que las críticas de los internalistas sobre los externalistas no logran superar las dificultades de la posición internalista y tampoco superan la capacidad comparativa del punto de vista externalista.

[Traducción de Gisela Hummelt N.] 